\title{
CODIS STR LOCI (CSF1PO, THOI, TPOX, vWA) GENETIC VARIATION ANALYSIS IN MADURESE
}

\author{
Ahmad Yudianto, ${ }^{1,2}$ Agung Sosiawan, ${ }^{2}$ Nola Margaret ${ }^{1}$ \\ ${ }^{1}$ Department of Forensic Medicine \& Medicolegal, Faculty of Medicine \\ ${ }^{2}$ Human Genetic Group Institute Tropical Disease, Universitas Airlangga
}

\begin{abstract}
ABSTRAK
Perkawinan dalam masyarakat di pulau madura pada daerah pelosok terutama daerah kepulauan terkecil madura masih terjadi antara kalangan mereka sendiri (endogami). Perkawinan endogami dilihat dari sudut pandang genetik akan meningkatkan frekuensi geneotip homozigot. Dalam variasi genetik pemeriksaan yang sering dipergunakan yakni STR pada DNA inti dan polymorphism pada mtDNA. Variasi genetik dalam populasi manusia mengalami evolusi, proses ini melalui akumulasi perubahan urutan DNA, yaitu melalui proses substitusi nukleotida yang berkembang jumlahnya seiring perkembangan arah garis keturunan. Sejauh ini variasi genetik populasi pulau madura belum banyak diketahui. Jenis penelitian ini adalah observasional analitik, untuk mengetahui variasi genetik pada STR CODIS (CSF1PO, THOI, TPOX, vWA) pada populasi pulau madura. Hasil penelitian ini menunjukkan, dari alel lokus CSF1PO, THOI, TPOX dan vWA rerata homozigot. Varian alel tersebut belum merupakan spesifik untuk suku madura yang bermukim di pulau madura, namun demikian varian ini akan memberi gambaran pola model perkawinan dalam suku Madura. Menurut Mustama (2007) menyatakan bahwa gene pool bukan hanya merupakan suatu kumpulan gen tetapi merupakan suatu sistem dinamis yang terorganisir dan memuat sejarah masa lalu dari suatu populasi. Setiap informasi genetik mempunyai aspek sejarah, antropologi dan statistik tertentu sehingga diperlukan koordinasi dan kolaborasi dari berbagai disiplin ilmu. (FMI 2016;52:1-6)
\end{abstract}

Kata kunci: variasi genetik, STR CODIS, suku madura

\begin{abstract}
Endogamy continues to occur among the Madurese people in rural areas of the island of Madura, especially those areas of the smallest islands around the mainland of Madura. Endogamy as seen from a genetic standpoint will increase the frequency of homozygote genotypes. With regard to genetic variations, STRs of nuclear DNA and polymorphisms in mtDNA are frequently examined. Genetic variations in human undergo an evolutionary process through the accumulation of changes in DNA sequence, i.e. through the process of nucleotide substitutions that evolves in number with the directional development of lineage. So far, the genetic variations among the populations in Madura Island have not been known. The present study was an observational analytical research with the purpose of determining the genetic variations in STR CODIS in the populations of Madura Island. Results indicated that, based on loci alelle: CSFIPO, THOI, TPOX, and $v W A$, there was homozygote genotypes. The allele variations is not specific for Madurese ethnic but this variations may represent married model in Madurese ethnic. According to Mustama (2007), a gene pool is not only a collection of genes but a dynamic system organized and containing the past history of a population. Any genetic information has certain historical, anthropological and statistical aspects necessitating an interdisciplinary coordination and collaboration. (FMI 2016;52:1-6)
\end{abstract}

Keywords: Genetic variations, CODIS STR, Madurese ethnic

Correspondence: Ahmad Yudianto, Department of Forensic Medicine \& Medicolegal, Faculty of Medicine, Universitas Airlangga. Email: yudi4n6sby@yahoo.co.id

\section{INTRODUCTION}

Madurese communities have a distinctive, unique, stereotypical, and stigmatic culture. Madura island population group is an ethnic group that largely until today still retain indigenous ancestral traditions coexisting in harmony with their religion. Marriage in the community of remote areas in Madura island, especially in smallest island, still occur among their own ranks (endogamy). Actually, the reason they practically do endogamous marriages is that the treasure they have will not lost/ moved to other family, as well as strong family ties. Endogamous marriage seen from a genetic genotype standpoint will increase the frequency of homozygote. Increased genetic homogeneity will appear if the endogamous marriage occurs continuously between generations up to the point where all alleles in one locus or all loci become homozygous (Bodmer \& Cavalli-Sforza 1976).

Ease of transportation in the territory of Madura island with its Suramadu bridge will open wider opportunities 
for the people of Madura island's mobilization. Madurese may look for a life partner outside the island so that exogamous marriage becomes possible more than endogamous marriage. According to Bodmer \& CavalliSforza (1976) concept of marriage between populations is the basis of population genetics analysis observed from genes frequency and explains the process of change in gene frequency in the population.

In genetic variation, the frequently used examination is the Short Tandem Repeats (STR) on deoxyribonucleic acid (DNA) nucleus and polymorphisms in mitochondrial DNA. Regions in STR are generally area that do not code for proteins, but has a simple repetition of the nucleotide motif. Alleles at STR locus vary greatly depending on the number of units of its motives, so that it can be used to study population sub structure and the short-term evolution as well as to measure the phylogenetic relationships between populations. Therefore STR is a marker for selection in observing population proximity from the point of ethnicity, language, culture and history of a population (Sahoo \& Kashyap 2005).

Based on the above observations, genetic variation will vary across each population and has a history of occurrence of those variations, so that the study of genetic variation in a population is still relevant. This study was expected to find genetic variations that include STR alleles pattern in populations of Madura island and yield loci mapping that can be used as a reference in Forensic DNA profiling in forensic DNA laboratory in Indonesia

\section{MATERIALS AND METHODS}

The type of this study was observational analytic conducted to determine genetic variation through CODIS STR (CSF1PO, Thoi, TPOX, VWA) in Madurese, with cross sectional design. Samples were Madurese ethnic groups residing on the island of Madura, parents or grandfather/grandmother married to fellow Madurese.

Material in this study were bloodstains-derived DNA. Materials for DNA extraction: DNAzol Reagent, 100\% ethanol solution, 70\% ethanol solution, and distilled water. Materials for PCR: PCR Mix, DW sigma. Primary Short Tandem Repeat (STR), which includes loci: THO1 (5'-CTGGGCACGTGAGGG CAGCGTCT-3' and 5'-TGCCGGAAGTCCATCCTCA CAGTC-3'), TPOX (5'-ACTGGCACAGAACAGGC ATCTAGG-3' and 5'-GGAGGAACTGGGAAC CACACAGGT-3'), CSF1PO: (5'-AACCTGAGTCTG CCAAGGACTAGC3 'and 5'-TTCCACACACCACT GGCCATCTTC-3'), VWA: (5'-CCTAGTGGATGAT AAGAATAATCAGT
ATG-3 'and 5'-GGACAGAT GATAAATACATAG GATGGATGG-3'). Materials acetate and loading dye, electrophoresis: Bis acryl-amid, Agarose, Temed, Tris Boric EDTA (TBE) 0.5\%, 100 bp marker, marker K562, and $0.03 \%$ bromphenol blue. Research instruments were cycle PCR, DNA sequencer ABI Prism 310, spectrophotometer, electrophoresis, whirlimixer, centrifuge, Eppendorf micropipette, micropipette tips, UV transluminator, Polaroid camera, Transsonic 310, spinator, Eppendorf tubes, and microwave.

\section{Bloodstain DNA extraction}

DNA was extracted by piercing the FTA card that contains the sample by means of Harris punch of 2.0 $\mathrm{mm}$, added $100 \mathrm{~mL}$, FTA purification reagent, and incubated for $10 \mathrm{~min}$ at room temperature. It was stirred with pipette and exhausted, repeated 3 times. $100 \mathrm{~mL}$ TE-1 buffer was entered, incubated for $10 \mathrm{~min}$ at room temperature, stirred with a pipette and then the TE-1 was removed. It was repeated 2 times. Samples were dried and stored with the addition of $30 \mathrm{~mL}$ TE buffer.

\section{PCR amplification}

DNA amplification by PCR method was done with the protocol of Promega Corp, 2001. PCR amplification for THO1, CSF1FO, TPOX was as follows: Phase I: Initial denaturation $96^{\circ} \mathrm{C}$ for 2 minutes; Phase II: Cycle 1 (10 times), consisting of subsequent denaturation $94^{\circ} \mathrm{C}$ for 1 minute, annealing $64^{\circ} \mathrm{C}$ for $1 \mathrm{~min}$, extension $70^{\circ} \mathrm{C}$ for 1 min $30 \mathrm{sec}$; 2 cycle (30 times), consisting of: denaturation $90^{\circ} \mathrm{C}$ for $1 \mathrm{~min}$, annealing $64^{\circ} \mathrm{C}$ for $1 \mathrm{~min}$, and extension $70^{\circ} \mathrm{C}$ for 1 minute 30 seconds. As for the VWA was follows: Phase I: Initial denaturation 960C for 2 minutes, phase II: Cycle 1 (10 times), which consists of Subsequent denaturation $940 \mathrm{C}$ for $1 \mathrm{~min}$, Annealing $600 \mathrm{C}$ for $1 \mathrm{~min}$, Extension $700 \mathrm{C}$ for $1 \mathrm{menit}$ 30 seconds, cycle 2 (20 times) denaturation $900 \mathrm{C}$ for 1 min, Annealing 600C for $1 \mathrm{~min}$, Extension $700 \mathrm{C}$ for 1 minute 30 seconds

\section{Electrophoresis}

This stage was done by using polyacrylamid composite agarose gel (PAGE) stained with silver staining. PAGE procedure was as follows: agarose gel was made from 30 cc EDTA $0.5 x$ Tris Boric and Agarose (LE Analytical Grade) 0.15 grams, heated in a microwave until crisp then cooled to a temperature of $50^{\circ} \mathrm{C}$. Then, it was added with acrylamid bis (N, N'-Methylenebisacrlaide) $4.5 \mathrm{cc}$ and Temed (N, N, N ', N'-Tetramethylenediamine) $15 \mathrm{ul}$, ammonium persulfate was further added $100 \mathrm{ul}$, and then poured into the mold (Gel bed), waited until it froze, DNA produced from PCR $12.5 \mathrm{ul}$ 
with loading buffer 2 ul was included and run at voltage of 70 volts for 2 hours.

PAGE silver staining procedure was as follows: drying: $(20 \%$ methanol $+2 \%$ glycerol $)$ in $100 \mathrm{cc}$ distilled water for 5 minutes, fixation $(10 \%$ ethanol $+5 \%$ acetic acid glycerol) in $100 \mathrm{cc}$ distilled water for 20 minutes, and washed/rinsed with distilled water 1x quickly. Staining: $0.1 \% \mathrm{AgN03}$ in $100 \mathrm{cc}$ distilled water for $50-80$ minutes. Developing: ( $\mathrm{NaOH}+100$ ul $1.5 \%$ Formalin) in $100 \mathrm{cc}$ of distilled water, then observed with a UV lamp until it looked clear.

\section{RESULTS}

Polymerase Chain Reaction (PCR) amplification process was begun with DNA template preparation through the process of cell lysis of the blood spots using FTA card kit. PCR results visualization on CSF1PO of 295-327 bp can be seen in Fig. 1.

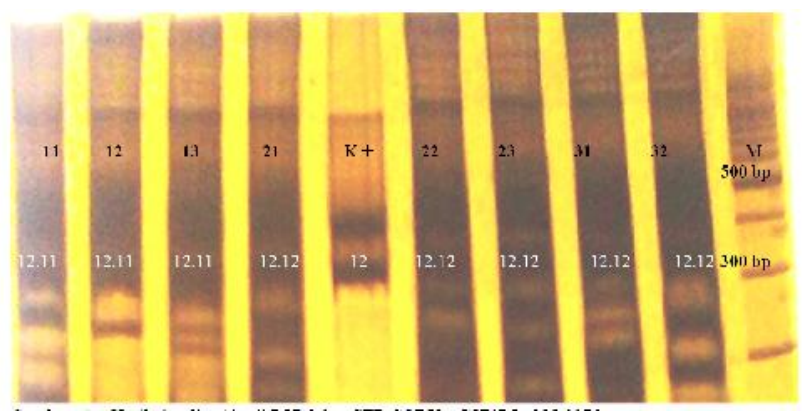

Fig. 1. Visualization of PCR results at CODIS STR loci CSF1PO; 295-327 bp. (M) markers, $(\mathrm{K}+)$ positive control K562 allele $12 \quad(11,12$, 13,21,22,23,31,32) samples.

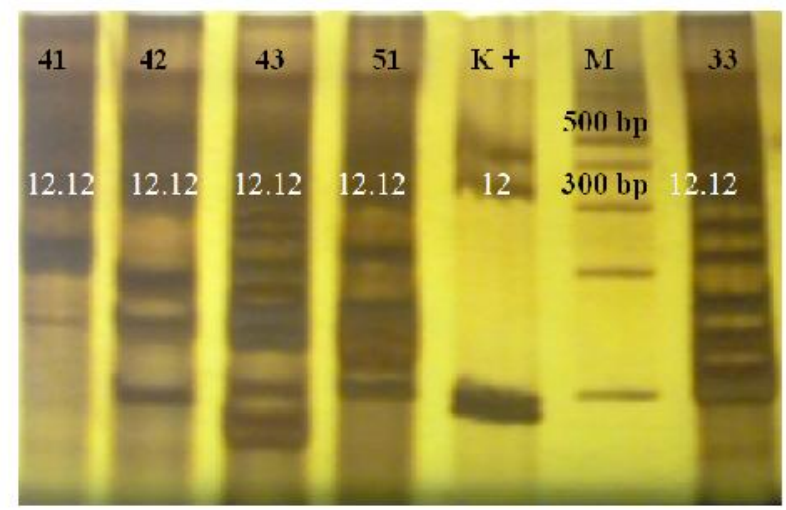

Fig. 2. Visualization of PCR results at CODIS STR loci CSF1PO; 295-327 bp. (M) markers, $(\mathrm{K}+)$ positive control K562 allele $12(41,42,43,51,33)$ samples

Fig. 2 shows the emergence of the tape/band between 295-327 bp that CSF1PO locus primer pairs used are specific, only attaches to the expected position. PCR process was carried out to amplify CODIS STR loci CSF1PO using primer pair M1 and M2. PCR products were analyzed by PAGE with silver staining. As well as showing allele homozygotes (12.12) and heterozygous (12.11).

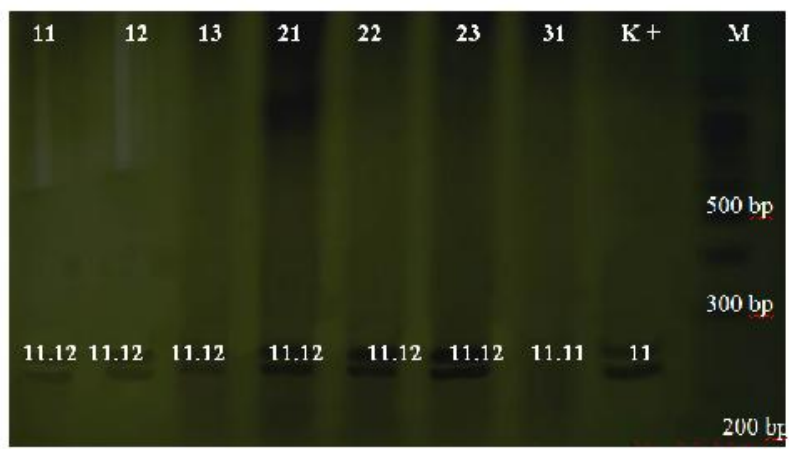

Fig. 3. Results visualization CODIS STR loci PCR results: TPOX; 224-252 bp. (M) markers, $(\mathrm{K}+)$ positive control K562 allele $11(11,12,13$, 21.22.23.31) samples

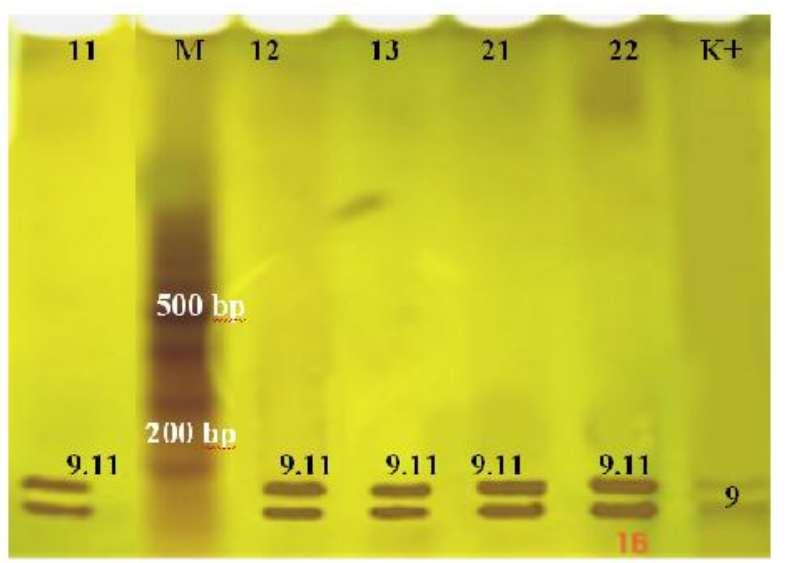

Fig. 4. Visualization of CODIS STR loci PCR results: Thoi; 179-203 bp. (M) markers, $(\mathrm{K}+)$ positive control K562 allele $9(11,12,13,21,22)$ samples.

In Fig. 3 above shows the emergence of the tape/band between 224-252 bp that TPOX locus primer pairs used are specific only stick to the expected position. The PCR process is carried out to amplify TPOX CODIS STR loci using primer pair M1 and M2. PCR products 
were analyzed by PAGE with silver staining staining showing homozygotes $(11: 11)$ and heterozygous $(11,12)$ allele.

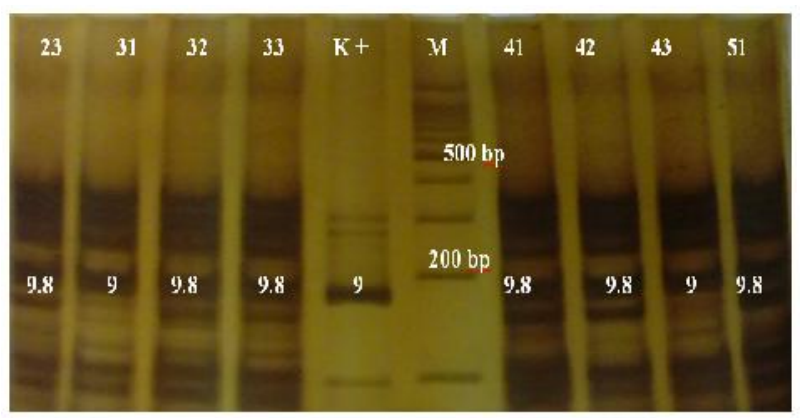

Fig. 5. Results visualization CODIS STR loci PCR results: Thoi; $179-203$ bp. (M) markers, $(\mathrm{K}+)$ positive control K562 allele $9(23,31,32,33$, $41,42,43,51)$ samples

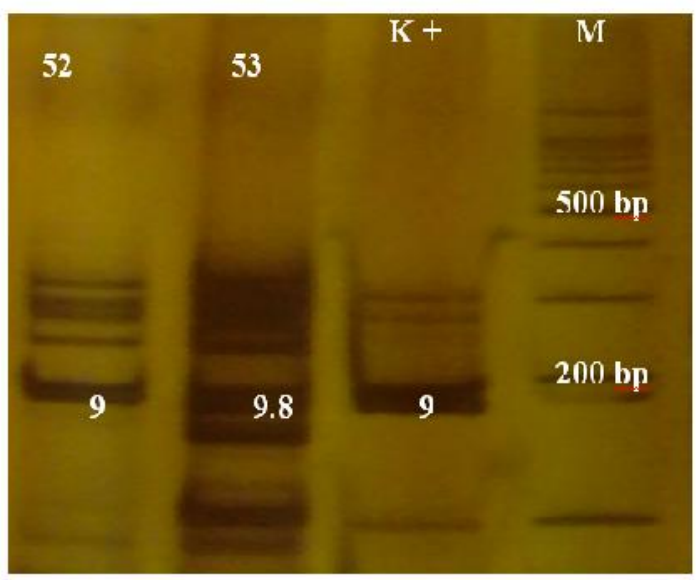

Fig. 6. Results visualization CODIS STR loci PCR results: Thoi; $179-203$ bp. (M) markers, $(\mathrm{K}+)$ positive control K562 allele 9, $(52,53)$ samples

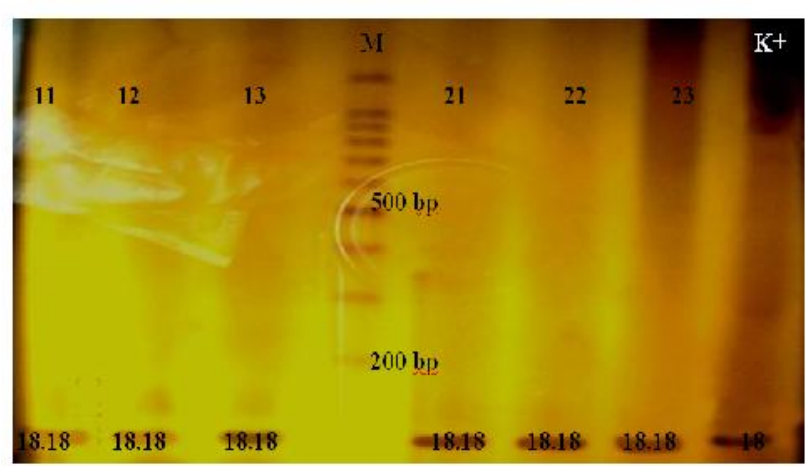

Fig. 7. Results visualization CODIS STR loci PCR results: VWA; 139-167 bp. (M) markers, $(\mathrm{K}+)$ positive control K562 allele $18 \quad(11,12,13$, $21,22,23)$ samples.
In the picture above shows the emergence of the tape/band between 179-203 bp that locus primer pairs used are specific Thoi just stick to the expected position. The PCR process is carried out to amplify Thoi CODIS STR loci using primer pair M1 and M2. PCR products were analyzed with PAGE silver staining, showing allele heterozygotes (9.11) (9.8) and homozygous (9.9).

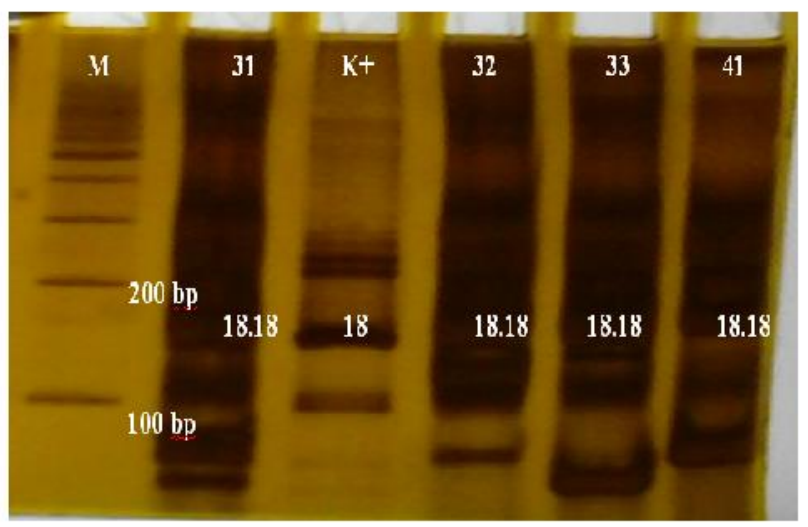

Fig. 8. The results visualization CODIS STR loci PCR results: VWA; $139-167$ bp. (M) markers, $(\mathrm{K}+)$ positive control K562 allele $18(31,32,33,41)$ samples

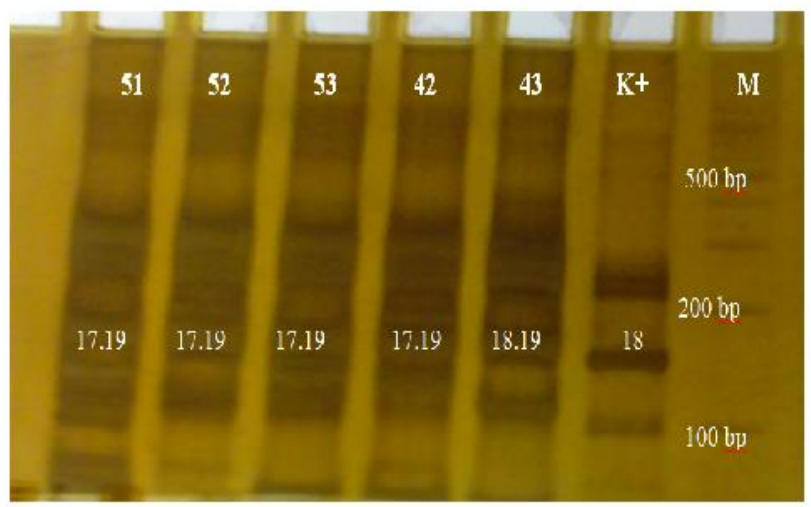

Fig. 9. Results visualization CODIS STR loci PCR results: VWA; $139-167$ bp. (M) markers, $(\mathrm{K}+)$ positive control K562 allele $18(51,52,53$, 42,43) samples

Figs. 7,8 and 9 show the emergence of the tape/band between 139-167 bp that VWA locus primer pairs used are specific, only attached to the expected position. The PCR process was carried out to amplify the CODIS STR loci VWA by using primer pairs M1 and M2. PCR products were analyzed with PAGE silver staining, showing homozygotes (18.18), heterozygous (17:19) (17:18) alleles. 
Table 1. Distribution of allelic variation CODIS STR loci (CSF1PO, Thoi, TPOX, VWA)

\begin{tabular}{llcccc}
\hline \multicolumn{1}{c}{ Marriage model } & Allele & CSF1PO & THOI & TPOX & vWA \\
\hline Madurese endogamy & Detected & 15 & 15 & 15 & 15 \\
\cline { 2 - 6 } & Allele number & 12.12 & 9.9 & 11.11 & 18.18 \\
& & $(73.33 \%)$ & $(20 \%)$ & $(60 \%)$ & $(66.67 \%)$ \\
& & 12.11 & 9.8 & 11.12 & 17.19 \\
& & $(26.67 \%)$ & $(46.67 \%)$ & $(40 \%)$ & $(26.67 \%)$ \\
$\mathrm{n}=15$ & & 9.11 & & 18.19 \\
& & & $(33.33 \%)$ & & $(6.67 \%)$ \\
\hline
\end{tabular}

Table 1 shows distribution of allelic variation in the CODIS STR loci CSF1PO, Thoi, TPOX, VWA, demonstrating differences in allele frequencies. Loci CSF1PO, TPOX and VWA show that homozygotes allele have the highest frequency. The results of this study indicate that allele of loci CSF1PO, Thoi, TPOX and VWA of 4 examined families contained a pair of alleles (averagely homozygous) found in each locus of Madura tribe. A pair of allele of the variant is not specific to Madurese who settled in Madura island, so it needs careful calculation based on population samples. However, a pair of alleles locus of this study may illustrate the pattern model of marriage among Madurese.

\section{DISCUSSION}

Based on the highest allele frequencies, the results of this study had differences from similar studies on Indonesian population (Untoro 2009), populations of Java, Sumatra, Sulawesi (Linace 2001). The difference may be due to differ-ence in samples where the research was on one population and traced up to 3 generations above/below and between samples were not mutually related. In this study, samples were those of native Madurese with endogamous marriage patterns, marrying the fellow Madurese. However, with the development of techno-logy and adequate transportation facilities, endogamous marriage patterns began to decline. To study the patterns of inheritance at the population level is necessary to understand Mendelian population. Mendelian population is a group of individuals of a species that reproduce sexually, live in a certain place at the same time and marriage occur between themselves (interbreeding) so that each will provide genetic contribution to the gene pool, which is a set of genetic information carried by all individuals in the population.

According to Stinson et al (2000) there are four main mechanisms that can alter gene frequencies and genotype in the population, namely mutation, selection, gene flow and genetic drift. Mutations and gene flow will increase variations in population. Gene flow is the exchange of genetic material between populations caused by migration and marriage. According to Cavalli-Sforza et al (1994), genetic drift occurs in the population in area which is closed, isolated or slightly receiving migrants from other regions. There are two circumstances that can lead to genetic drift. They are the bottleneck, where the population size is reduced at a certain time, and founder effect in which all individuals in a population can be traced back to a small number of individuals of origin. Genetic diversity decreases with migration. When a small group of our ancestors migrated to new areas, they basically carry within them a smaller sample of genetic diversity of the original communities.

The results of this study recommend that research on population or other medical fields should not only focused on genetics alone, but also take into account culture and customs of a population. Gene pool is not only a collection of genes, but a dynamic system that is well organized and includes the past history of a population. Every aspect of genetic information has history, anthropology and certain statistics so that it necessitates coordination and collaboration of various disciplines.

\section{CONCLUSION}

Analysis of CODIS STR loci CSF1PO, Thoi, TPOX, VWA in Madurese shows high genotype/homozygous allele in their gene pool. Local endogamous marriage patterns is most prevalent although in a small percentage $(48 \%-55 \%)$. From genetic variation analysis based on history, it is suspected that Madurese had experienced suspected genetic drift and founder effects exists. It is visible in the gene pool of the Madurese, which mostly is homozygous.

\section{REFERENCES}

Bodmer WF and Cavalli-Sforza LL (1976). Genetics, Evolution and Man, San Fransisco, WH Freeman and Company

Cavalli-Sforza LL, Menozzi P, Piazza A (1994). The History and Geography of Human Genes, Princeton, Princeton University Press 
Linacre AM, Phillips P, Wally A, Goodwin W (2001). STR data for the SGM Plus loci from three Indonesian populations. Forensic Sci Int 123, 232-234

Sahoo S and Kashyap VK (2005). Influence of language and ancestry on genetic structure of contiguous populations: A microsatellite based study on populations of Orissa. BMC Genetics 6
Stinson S, Bogin B, Hush-Ashmore R, O'Rourke D (2000). Human Biology: An Evolutionary and Biocultural Perspective, New York, Willey-Liss, p 4-7 Untoro E, Atmaja DS, Pu CE, Wu FC (2009). Allele frequency of CODIS 13 in Indonesian Population. Legal Medicine 11, S203-S205 